\title{
THE IMPACT OF STRATEGIC LEADERSHIP ON ORGANISATIONAL AMBIDEXTERITY AT THE KING ABDULLAH II DESIGN AND DEVELOPMENT BUREAU (KADDB)
}

\author{
Hamza Alzawahrah $^{1} \square$ (1) and Maha Alkhaffaf ${ }^{2}$ (1) \\ Business Department, World Islamic Sciences University, Jordan \\ ${ }^{2}$ MIS Department, World Islamic Sciences University, Jordan
}

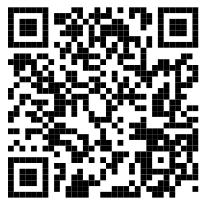

Received 2 May 2021

Accepted 17 May 2021

Published 29 May 2021

Corresponding Author

Hamza Alzawahrah, alkhaffaf@ya

hoo.com

DOI $10.29121 /$

IJOEST.v5.i3.2021.193

Funding: This research received no specific grant from any funding agency in the public, commercial, or not-for-profit sectors.

Copyright: (C) 2021 The Author(s). This is an open access article distributed under the terms of the Creative Commons Attribution License, which permits unrestricted use, distribution, and reproduction in any medium, provided the original author and source are credited.

\section{ABSTRACT}

This study aimed at identifying the impact of strategic leadership dimensions, such as defining strategic direction, investing strategic capabilities, and implementing balanced organisational supervision, on the organisational ambidexterity dimension at the King Abdullah II Design and Development Bureau (KADDB).

The sample consisted of the directors at top and middle management at KADDB, totalling 92 directors. Further, a questionnaire was used as a tool for data collection through Google Forms for the convenience of data collection and edition. 86 valid questionnaires were retrieved before the analytical descriptive approach was used, and, following this, data analysation and hypotheses tests were carried out according to the descriptive statistic measures and statistical analysis program Smart PLS v. 3.

The results indicated high relative importance of the strategic leadership and organisational ambidexterity at KADDB, and, notably, a statistically significant impact of strategic leadership was approved on organisational ambidexterity at KADDB at the significant level $(\mathrm{P} \leq 0.05)$. This significant impact was approved for all the dimensions of strategic leadership except for the dimension 'promoting human capital'.

In light of the findings, the researchers recommended that KADDB should: improve organisational ambidexterity and its activities (exploration and exploitation) by organising special steering committees for this purpose within the business development department at KADDB; pay more attention to environmental scanning; balance the patterns of results-based monitoring and control; empower employees; and, finally, improve the current recruitment, promotion, and reward systems.

Keywords: Strategic Leadership, Organisational Ambidexterity, King Abdullah II Design and Development Bureau (KADDB) 


\section{INTRODUCTION}

The world has witnessed many rapid changes over the course of the $21^{\text {st }}$ century, and this has resulted in many rapid developments in the business environment. This has imposed great challenges on business organisations in all fields: as advances in Information and Communication Technology have led to the opening of markets and business organisations to the world, the international legislations issued by the World Trade Organisation (and relevant international organisations) have also contributed to an increase in competition in business markets. All these (amongst other reasons) have forced organisations to search for unconventional management methods to help them withstand in business markets and continue to provide added value to stakeholders.

Business organisations have recently increased their interest in enhancing their organisational ambidexterity by improving their strategic leadership practices due to its great role in improving its performance in the short- and long-term, thus improving organisations' abilities to explore and exploit opportunities. Indeed, this is a major reason behind why so many organisations are able continue to operate successfully and achieve competitive advantage and precedence Elfindah (2020). Such exploration and exploitation activities have become an urgent necessity for organisations, especially in light of the momentum of competition in the business environment; this is because organisational ambidexterity contributes to improving the performance of organisations, as well as the fact that it also increases organisations' efficiency and resilience and maintains their sustainability Sun et al. (2018).

Moreover, strategic leadership is the best solution to overcome ambiguity, uncertainty, and complexity in the business environment by fusing leadership practices with strategic practices to form a solid knowledge union capable of implementing the vision and strategy of the organisation to achieve its goals Najmaei et al. (2017). Moreover, strategic leadership practices enhance the competitive advantage of business organisations and the sustainability of their business by uniting the efforts of individuals via the optimal utilisation of available resources to achieve the goals of the organisation. Furthermore, it also casts a great positive impact on the performance of employees and the ability of organisations to achieve their goals and innovate new products. This is done by inspiring and motivating workers, as well as giving them the necessary powers to participate effectively in decision-making Pitelis and Wagner (2019). 
The KADDB was established in 1999 in Jordan, and is an experienced pioneering institution in the field of defence. It is considered to be at the forefront of institutions that entered the fields of artificial intelligence, cybersecurity, cryptography, and drones, in addition to three-dimensional printing and wireless jamming systems. Indeed, designing, development, testing, evaluation, and finding optimal solutions in defence fields are the core of the KADDB's work Farghal (2019).

The defence and security industries are more complex and sensitive than other industries, and this is due to their use of the most recently available technologies, as well as its high requirements for accuracy, quality, and safety standards. Further to this, huge budgets are allocated to achieve precedence in owning defence systems, the military's worldwide spending amounting to $\$ 1,917$ billion in 2019, the Middle East's and South Africa's share being $\$ 170.5$ billion (sipri.org). Separately, the state of political instability in the Middle East and South Africa (which led to the outbreak of some wars and conflicts that undermined internal security in some countries) forced all such countries to enhance their defence and security capabilities. Hence, the opportunity to improve, develop, and expand the activities of the KADDB in the region has become urgent, especially in light of the KADDB's strengths and opportunities, represented by political stability in Jordan, strategic location, the balance of foreign policy with neighbouring countries (and internationally), strategic partnerships with developed countries in the field of defence industries, and the limited defence industries in the Arab region.

With all of the above in mind, this study aims to identify the impact of strategic leadership on organisational ambidexterity in the KADDB.

\section{LITERATURE REVIEW}

\subsection{STRATEGIC LEADERSHIP}

Leadership is one of the most important activities that the administrations of organisations practice: effective leadership aids organisations in achieving a competitive advantage by uniting the efforts of individuals via the optimal use of the available resources to achieve the organisation's goals Pitelis and Wagner (2019), Samba et al. (2018). In the same vein, the absence of good leadership often leads to the absence/weakness of the spirit of enthusiasm amongst workers to carry out their duties creatively and efficiently, additionally reducing their ability to respond to changes in the business environment Al-Zahrani (2018).

Today's leaders face a rapidly changing and disruptive business environment-and, indeed, this makes change one of the most important problems that must be dealt with, no matter how efficiently. This is done by enhancing the participation of individuals in solving these problems in such a way that the leader's direction is understood, faith is in him, and the necessary support is provided to achieve it. Indeed, in light of this, strategic leadership is one of the most important leadership models that have proven effective in improving the efficiency of organisations to cope with a highly turbulent and changing environment Najm et al. (2012). Many researchers have been interested in leadership in general and strategic leadership in particular as one of the most important elements for the successful implementation of strategies, and such researchers have indicated the absence of strategic leadership as being one of the most important obstacles to implementing strategies effectively MITCHELL et al. (2007), Pearce and Robinson (2007), Hrebiniak (2008). To this end, the strategy should be put into implementation via tactical plans that push the organisation towards the desired strategic direction Beer and Eisenstat (2000), Kaplan and Norton (2004), Hrebiniak (2008). 


\subsubsection{THE CONCEPT OF STRATEGIC LEADERSHIP AND ITS IMPORTANCE}

The concept of strategic leadership is considered to be one of the relatively modern management concepts in administrative literature, as the origin of this concept goes back to military concepts, quickly moving to contemporary management concepts due to the rapid changes in the business environment Wright et al. (2018). There is a variation in the concept of strategic leadership whereby some link the concept of strategic leadership with the ability to clarify the strategic vision of the organisation (or part of it), as well as the ability to motivate others and push them to believe in and understand it. Further to this, it is also expressed as the ability to anticipate and maintain flexibility, as well as to enable others to make strategic change whenever circumstances require Hill and Jones (2016).

As a whole, strategic leadership practices are crucial for organisations, since they enhance the competitive advantage of business organisations and the sustainability of their business by uniting the efforts of individuals via the optimal utilisation of the available resources to achieve the goals of the organisation. Further to this, it additionally casts a great positive impact on the performance of employees and the ability of organisations to achieve their goals and innovate new products Sibghatullah and Raza (2020), Pitelis and Wagner (2019). Additionally, it plays a big role in managing crises in organisations; that is, how to understand the strategic leader's perspective towards the environmental turmoil and ambiguity, as well as how to act rationally towards it A. M. Obeidat and Thani (2020), Sayed and Theeb (2019).

\subsubsection{THE DIMENSIONS OF STRATEGIC LEADERSHIP}

Researchers differ when it comes to determining the dimensions of strategic leadership according to their different intellectual orientations. Table 1 shows the strategic leadership dimensions used by a number of researchers.

In line with the current study, the most important strategic leadership dimensions were chosen as follows:

- Defining Strategic Direction - This is the scientific development of long-term plans to effectively manage opportunities and challenges in the (external) business environment in view of the strengths and weaknesses of the organisation (the internal environment). This is what is known as a SWOT analysis, and the activities of this dimension involve defining the vision, mission, and achievable goals, as well as developing strategies and policies for the organisation Wheelen et al. (2017). Determining the strategic direction involves developing a long-term future strategic vision for the organisation that contains an incentive for individuals to implement, thus allowing leaders to motivate and empower the work team to create efficient and effective organisational models so that everyone works as one team to develop organisational growth Kitonga (2017). The mission of the organisation is the reason for its existence-it shows what the organisation provides to society from the products and what is the added value from its existence-, and so the thorough formulation of the organisation's mission clarifies the basic and distinct purpose of the organisation from other organisations. Indeed, Sidhu (2004) has shown that organisations whose mission explicitly describes target customers and the technology used grow larger than organisations whose mission does not make it clear.

- Promoting Human Capital- Human resources are one of the most important resources that an organisation relies on to respond to environmental changes in a creative manner-and the importance of human resources lies in their ability to improve the efficiency and effectiveness of organisations, providing a competitive advantage as a result Najm et al. (2012), A. M. Obeidat et al. (2018). This is what makes human resources the most important component of knowledge capital in the organisation: the existence of the organisation depends on its human resources-and by human capital, we mean all the capabilities, knowledge, skills, creativity, behaviour, commitment, wisdom, and experience of the work team, including the values, attitudes, and customs of the 
Table 1 Strategic Leadership Dimensions

\begin{tabular}{|c|c|c|c|c|c|c|c|c|c|c|c|c|c|c|c|c|c|}
\hline $\begin{array}{l}\text { Study } \\
\text { Dimension }\end{array}$ & $\begin{array}{l}\text { A.M } \\
\text { dat } \\
\text { and } \\
\text { Tha] } \\
\text { (202 }\end{array}$ & $\begin{array}{l}\text { Pal- } \\
\text { ladan } \\
\text { et } \\
\text { al. } \\
\text { (201t }\end{array}$ & $\begin{array}{l}\text { Muz } \\
\text { et } \\
\text { al. } \\
\text { (201 }\end{array}$ & $\begin{array}{l}\text { Leal } \\
(201\end{array}$ & $\begin{array}{l}\text { Gill } \\
\text { (201 }\end{array}$ & $\begin{array}{l}\text { Hitt } \\
\text { et al. } \\
(2010)\end{array}$ & $\begin{array}{l}\text { Hitt } \\
\text { et } \\
\text { al. } \\
(2009\end{array}$ & $\begin{array}{l}\text { Pis- } \\
\text { apia } \\
(2009\end{array}$ & $\begin{array}{l}\text { Ire- } \\
\text { land } \\
\text { and } \\
\text { Hitt } \\
\text { (2005 }\end{array}$ & $\begin{array}{l}\text { Davi } \\
\text { and } \\
\text { Davi } \\
\text { (200 }\end{array}$ & $\begin{array}{l}\text { Hoskis } \\
\text { et al. } \\
\text { (2004) }\end{array}$ & $\begin{array}{l}\text { Boal } \\
\text { and } \\
\text { Hooi } \\
\text { jberg } \\
\text { (200 }\end{array}$ & $\begin{array}{l}\quad \text { Neu- } \\
\text { mann } \\
\text { and } \\
\text { Neu- } \\
\text { mann } \\
\text { (1999) }\end{array}$ & $\begin{array}{l}\text { Hage } \\
\text { et } \\
\text { al. } \\
\text { (199£ }\end{array}$ & $\begin{array}{l}\text { Thomp } \\
\text { son } \\
\text { (1997) }\end{array}$ & $\begin{array}{l}\text { House } \\
\text { and } \\
\text { Aditya } \\
\text { (1997. }\end{array}$ & Frequency \\
\hline $\begin{array}{l}\text { Defining } \\
\text { Strategic } \\
\text { Direction }\end{array}$ & $X$ & $X$ & $X$ & $X$ & $X$ & $X$ & $X$ & $X$ & $X$ & & $X$ & $X$ & $X$ & $X$ & $X$ & $X$ & 14 \\
\hline $\begin{array}{l}\text { Enhancing } \\
\text { Organi- } \\
\text { sational } \\
\text { Culture } \\
\text { with Ethical } \\
\text { Practices }\end{array}$ & $X$ & $X$ & $X$ & $X$ & $X$ & $X$ & $X$ & $X$ & $X$ & & $\mathrm{X}$ & $X$ & $X$ & $X$ & $X$ & & 12 \\
\hline $\begin{array}{l}\text { Promoting } \\
\text { Human } \\
\text { Capital }\end{array}$ & $X$ & $X$ & $X$ & & $X$ & & $X$ & $X$ & $X$ & $X$ & $X$ & & $X$ & $X$ & $X$ & $X$ & 12 \\
\hline $\begin{array}{l}\text { Implementing } \\
\text { Balanced } \\
\text { Organi- } \\
\text { sational } \\
\text { Supervision }\end{array}$ & $X$ & $X$ & $X$ & $X$ & $X$ & $X$ & $X$ & $X$ & $X$ & & $X$ & & & & & X & 10 \\
\hline $\begin{array}{l}\text { Investing } \\
\text { Strategic } \\
\text { Capabilities }\end{array}$ & X & & & & $X$ & $X$ & $X$ & $X$ & $X$ & & $X$ & & & & & & 7 \\
\hline $\begin{array}{l}\text { Effective Use } \\
\text { of Technol- } \\
\text { ogy }\end{array}$ & & & & & $X$ & & & & $X$ & & & & & & X & & 3 \\
\hline $\begin{array}{l}\text { Translating } \\
\text { Strategy into } \\
\text { Business } \\
\text { Procedures }\end{array}$ & & & & & & & & & & $X$ & & & $X$ & & & & 2 \\
\hline $\begin{array}{l}\text { Selecting } \\
\text { and Devel- } \\
\text { oping the } \\
\text { New Gen- } \\
\text { eration of } \\
\text { Leaders }\end{array}$ & & & & & & & & & & & & $X$ & & & & $X$ & 2 \\
\hline $\begin{array}{l}\text { Defining } \\
\text { Resources } \\
\text { and Rela- } \\
\text { tionships }\end{array}$ & & & & & & & & & & & & & & & & $X$ & 1 \\
\hline $\begin{array}{l}\text { Defining } \\
\text { Organi- } \\
\text { sational } \\
\text { Goals }\end{array}$ & & & & & & & & & & & & & & & & $X$ & 1 \\
\hline
\end{tabular}


organisation's workers Abualoush et al. (2018).

- Investing Strategic Capabilities - Resources are the assets and the building blocks of organisations, and the resources are divided into tangible resources, such as equipment, buildings, funds, and human resources, and intangible resources such as technology, culture, and the reputation of the organisation. Meanwhile, capacity refers to an organisation's ability to utilise its resources, and consists of work procedures and routines that manage the process of interaction of different resources to transform inputs into outputs. Marketing capabilities, operations, human resource management, etc., are some of the types of capability, and, upon continuous modification, development, and reformulation of these capabilities, they become more responsive to environmental changes and become dynamic capabilities. When the organisation has multiple dynamic capabilities at all levels, it reaches what is called core or strategic ability/competence, or full ability. Notably, if the organisation's strategic capabilities exceed the capabilities of its competitors, it has 'distinctive competencies', which have four characteristics, according to the VRIO model: value, scarcity, organisation, and difficulty of imitation Wheelen et al. (2017).

- Enhancing Organisational Culture with Ethical Practices - An organisation's culture consists of beliefs, expectations, and values that employees learn, share, and pass on from generation to generation. This usually reflects the founder's values and mission, and, in turn, the organisational culture plays an important role in spreading a sense of the organisation's identity among workers, as well as in generating commitment amongst workers for something more important than their personal interests. It also adds stability to the organisation as a social system, since the organisational culture constitutes a framework that workers use to understand the activities of the organisation. Indeed, it serves as a guide for acceptable behaviour in the organisation, and, in turn, it controls the behaviour of the employees-which is reflected in the performance of the organisation Ravasi and M (2016). The ethical practices of the leader are one of the biggest influences on the organisational culture and the performance of employees through his many qualities, such as humility, concern for the public interest, justice amongst workers, and responsibility and respect for everyone. Further to this, the leader should be a model in values and provide meaning to workers with his personal characteristics Pitelis and Wagner (2019).

- Implementing Balanced Organisational Supervision- The control system aims to ensure that the organisation achieves its planned goals by comparing actual performance with planned performance, providing feedback to leaders to evaluate results and take corrective actions as needed along the way. The control process is carried out by identifying the activities to be measured, setting performance standards, measuring the actual performance, and then comparing it with the approved standards before taking the necessary corrective actions in the event of a deviation in the actual performance. To this end, the appropriate corrective action is determined by answering some questions such as (according to Wheelen et al. (2017): was deviation purely a coincidence? Were the actions executed incorrectly? Are the procedures appropriate to achieve the desired standards? Who is the best person to take corrective action? Indeed, strategic control is a major component of strategic leadership, especially in the implementation phase, and it involves the monitoring and evaluation of the effectiveness of strategy implementation Norzailan et al. (2015).

\subsection{ORGANISATIONAL AMBIDEXTERITY}

'Ambidexterity' refers to the skill of using both hands in writing (Oxford Dictionary), and is a metaphor for the ability to do two different tasks that require contradictory skills at the same time. Duncan (1976) was the first to use the term 'organisational ambidexterity' to refer to the ability of organisations to design dual organisational structures, 
in turn facilitating the process of initiating the application of innovation stages. Furthermore, many researchers also emphasised that organisational ambidexterity has become an urgent necessity for organisations, especially in light of the momentum of competition in the business environment. In this way, organisational ambidexterity contributes to improving the performance of organisations, and, indeed, organisational ambidexterity increases the efficiency and flexibility of organisations and maintains their sustainability Sun et al. (2018). Moreover, organisational ambidexterity is an indication of the ability of organisations to continue to operate successfully in light of rapid changes in technology and markets - and this is done by engaging in exploration and exploitation activities that enable the organisation to compete in technology and mature markets by controlling the activities of the organisation to ensure its efficiency O’Reilly and Tushman (2008).

The main challenge before practicing organisational ambidexterity is the coordination of any exploration and exploitation operations at the same time and place Jansen et al. (2010). Here, Bodwell and Chermack (2010) identified a number of characteristics that organisations must possess in order to be described as ambidextrous organisations: the skill of perception (the ability to identify opportunities), and possession of specific mechanisms to study the internal and external environment, as well to identify the strengths, weaknesses, opportunities and threats. Furthermore, Preda (2014) identified a number of conditions that must be met in organisations in order for them to be ambidextrous organisations: the consensus of senior management on the organisation's strategy; realising the importance of organisational ambidexterity to achieve it; formulating a strategy in a manner that facilitates the investment of organisational skill activities; understanding workers at all levels, as well as reasons for exploitation and exploration activities; and the assurance of continuous cooperation between the various organisational units.

\subsubsection{THE CONCEPT OF ORGANISATIONAL AMBIDEXTERITY AND ITS IMPORTANCE}

Organisational dexterity refers to the striving to exploit existing resources and explore new possibilities at the same time, and is done via the reconciling of operations that focus on the organisation's exploitation of its competitive position, with exploration that focuses on new opportunities in the future Snehvrat et al. (2018). The researchers were unanimous when it came to their definition concerning organisational ambidexterity when it came to the organisations' pursuits of simultaneous exploration and exploitation activities, as well as the ability to achieve a balance between them, instead of choosing one of the two activities, or the domination of one of them over the other. Indeed, organisational ambidexterity increases the profits of organisations and ensures that they remain in a good competitive position in the long term Jansen et al. (2010).

Many researchers have pointed out the importance of organisational ambidexterity, as it plays a major role in the successful continuation of organisations' work: it enhances the capabilities of organisations in creating new products and services on the one hand whilst continuing to make improvements to its current operations on the other. Furthermore, the interest in exploration and exploitation activities positively affects the growth of sales volumes, and organisational ambidexterity enables organisations to face challenges in the business environment. Indeed, in this vein, many studies have shown that this is closely related to the improvement organisation performance Gibson and Birkinshaw (2004). Organisational ambidexterity additionally increases the interest of workers and improves creativity, innovation, and innovative culture activities within business organisations Al-Ammary et al. (2020). Moreover, organisational ambidexterity plays a major role in organisations' ability to deal with environmental disruption by increasing the efficiency of leaders in anticipating opportunities and threats, as well as when it comes to adopting dynamic methods in seizing opportunities, avoiding threats, and meeting new customer desires Mohammad and Hijawi (2019). 


\subsubsection{THE DIMENSIONS OF ORGANISATIONAL AMBIDEXTERITY}

Many researchers have used the two dimensions of exploitation and exploration as dimensions of organisational ambidexterity, such as Palm and Lilja (2017) and O'Reilly and Tushman (2008). The researchers used these same dimensions, as follows:

- Exploitation- Exploitation is the acquisition of opportunities to directly create value in the form of a new good/service and a means of satisfying customers' needs by analysing and understanding the need, thus creating higher value in the short term. Furthermore, exploitation enables an organisation to compete by understanding market requirements and establishing good customer relationships Judge and Blocker (2008). Palm and Lilja (2017) are of the view that exploitation enables the organisation to develop its operations, in turn adding value to the work of the organisation and meeting customer requirements-and thus expanding existing products and services into existing markets. Exploitation processes focus heavily on efficiency, improvement, and services, thus contributing to the realisation of the organisation's vision and business strategies O'Reilly and Tushman (2011). Judge and Blocker (2008) identified a set of capabilities that an organisation must possess in order to be able to achieve the exploitation activity: the ability to serve clients in a timely and optimal manner; the provision of products that meet customer desires; maintaining the organisation's brand; and protecting the intellectual assets that you own.

- Exploration- Exploration is the ability to discover opportunities in a business environment, and is considered to be one of the most important activities that organisations should not neglect due to the fact that the impact of a discovered opportunity reflects positively on the organisation in many areas, the most important of which being the survival of the organisation in the business market. The term 'exploration' is associated with research, experimentation, employment, and resilience activities Schreuders and Legesse (2012). Dhliwayo and Vuuren (2007) defined exploration as 'a vision that is concerned with introducing new goods and services to enable the organisation to outperform competitors while anticipating future needs and preparing for change'. Exploration operations include activities to search for opportunities resulting from changes in the business environment-which confirms the need for exploration activities to be flexible O'Reilly and Tushman (2011). Furthermore, in order for organisations to achieve exploration, they must possess a set of skills: the ability to adapt to a dynamic work environment; to be able to explore opportunities in the business environment in which they work; to maintain distinguished relationships with stakeholders (especially clients) to stay informed about their future needs-an opportunity for any organisation Danneels (2003).

\section{RESEARCH METHODOLOGY}

\subsection{HYPOTHESES DEVELOPMENT AND THE RESEARCH MODEL}

As mentioned previously, some studies have examined the variables that the researchers used in this study with different dimensions depending on the nature of the studies and their objectives. Amongst these studies is Baškarada et al. (2016) (entitled 'The Impact of Strategic Leadership on Organisational Ambidexterity in Australian Defence Industry Firms'), which concluded there to be an impact of strategic leadership on organisational ambidexterity in Australian defence industries companies. They additionally concluded that the type of strategic leader' behaviour that enhances exploitation is exemplified by training, performance management, and knowledge management, whilst the type of behaviour that promotes exploration is commitment, visibility, risk tolerance, delegation of authority, and inclusiveness. Meanwhile, Zaid and N (2016) (entitled 'The Impact of Strategic Leadership on Organisational Ambidexterity: A Field Study on Jordanian Chemical Industry Companies') found there to be a statistically significant impact of strategic leadership on the organisational ambidexterity in the studied Jordanian chemical industries com- 
panies, the researcher in turn indicating the necessity of increasing managers' interests in the skills of vision, focus, and implementation in order to achieve better performance and to ensure the continuation of successful work.

In order to achieve the objectives of the study and to answer its questions related to research on strategic leadership and its impact on organisational ambidexterity at KADDB, the study hypotheses were formulated as follows:

Ho1: There is no statistically significant impact at a significant level $(\mathrm{P} \geq 0.05)$ for strategic leadership in its dimensions (defining strategic direction, investing strategic capabilities, promoting human capital, enhancing organisational culture with ethical practices, and implementing balanced organisational supervision) on organisational ambidexterity with its dimensions (exploration; exploitation) at KADDB.

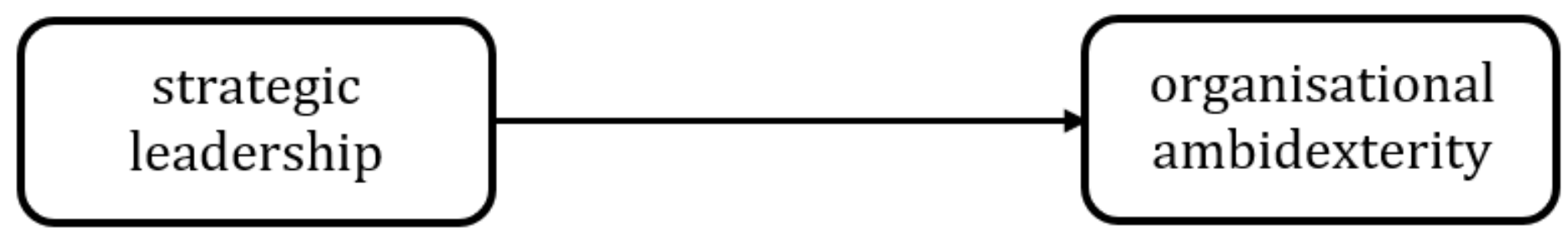

Figure 1 Research Model

Source: Hitt et al. (2011)

\subsection{THE STUDY POPULATION AND SAMPLE}

The comprehensive survey strategy was adopted due to the small size of the study population. All the members of the study population were notably chosen to answer the paragraphs of the study questionnaire. Such a strategy is appropriate in the event that the study population is small, or in situations whereby the garnering of special information is the goal Neuman (2000).

The study population is represented by all the directors of the executive and supervisory management in KADDB, of which there are 92 directors. These directors represent the decision-makers in the KADDB.

Only 86 questionnaires were answered (93.5\%) due to the fact that a number of the study sample was occupied with working and travel conditions, as well as annual leave. Regardless, $93.5 \%$ is a statistically acceptable percentage: it exceeds the minimum size of the statistically acceptable study sample, which was calculated based on Sekaran and Bougie (2016) method, as follows:

$$
\begin{aligned}
& n=t^{2} P(1-P) \backslash d^{2} \longrightarrow n=1.96^{2} * 0.50(1-0.50) \backslash(0.05)^{2}=385 \\
& \overline{\mathbf{n}}=n \backslash(1+n \mid N) \longrightarrow \overline{\mathbf{n}}=385 \backslash(1+385 \backslash 92)=74.256 \approx 74
\end{aligned}
$$

Where $\mathrm{n}$ represents the statistically acceptable sample size, regardless of the size of the study; $\mathrm{N}$ represents the size of the study population; $\bar{n}$ represents the statistically acceptable sample size (adjusted for the size of the study population $\overline{\mathrm{n}}$ ); t represents the number of standard units and equals 1.96 for a $95 \%$ confidence level; $d$ represents 
the limits of permissible error, equal to $5 \%$ for a $95 \%$ confidence level; and P represents $50 \%$ of the vocabulary possessing research characteristics.

As can be noted note from Table 2 , the number of males in the study sample amounted to 78 individuals, at a percentage $90.7 \%$ of the total number of the sample, the number of females meanwhile totalling 8 individuals, or $9.3 \%$ of the study sample. These percentages indicate that the majority of the members of the executive and supervisory management of the King Abdullah II KADDB for Design and Development are male, and this can be attributed to the nature of the work in the defence industries, which requires good experience in weapons, machinery, and military equipment-as well as the nature of their use in the field, which requires continuous field contact with users in the armed forces, security services, and sister and friendly armies in the region, which requires physical effort, relatively long working hours, continuous travel, and work during official holidays in line with the working days of the foreign countries with which he deals. This is not commensurate with the nature of females in our society, and thus reduces the opportunity for them to work in KADDB, with the exception of some office jobs. It can be deduced from these ratios that KADDB is interested in employing people with high scientific qualifications, as the nature of the KADDB's work in research, design, and development requires distinctive skills and knowledge amongst workers. We additionally noted that the heads of the departments formed the largest number of the study sample, as their numbers reached 66 and a percentage of $76.7 \%$ of the study sample. These percentages additionally indicate that KADDB is interested in employing young people in executive and supervisory administrative positions, depending on their scientific qualifications, abilities, and skills, and not the number of years of experience, since the total number of individuals with less than 20 years of experience in the executive and supervisory administrative levels of the KADDB constituted 64 individuals, making up $74.4 \%$ of the total study sample.

\begin{tabular}{llll}
\hline Table 2 Population Characteristics & & \\
\hline Variale & Discerption & Frequency & $\mathbf{\%}$ \\
Gender & Male & 78 & $90.7 \%$ \\
\hline & Female & 8 & $9.3 \%$ \\
Qualification & PhD & 4 & $4.7 \%$ \\
& MA & 36 & $41.9 \%$ \\
\hline & $\mathrm{BA}$ & 46 & $53.4 \%$ \\
\hline Position & Director & 8 & $9.3 \%$ \\
\hline & Dept. Head & 12 & $14.0 \%$ \\
\hline Experience (years) & Sec. Head & 66 & $76.7 \%$ \\
& $<10$ & 18 & $20.9 \%$ \\
\hline & $\geq 10<15$ & 18 & $20.9 \%$ \\
\hline & $\geq 15<20$ & 28 & $32.6 \%$ \\
\hline & $\geq 20$ & 22 & $25.6 \%$ \\
\hline
\end{tabular}

\section{RESEARCH METHOD}

The study tool was designed after reviewing a number of previous studies and research related to the subject of the current study-and, in order to sufficiently reflect the study's hypotheses and objectives, the study questionnaire was divided into two parts: the demographic information of the study population (i.e., gender; position; educational qualifications; number of years of experience); and the study variables and their main dimensions, divided into two parts: the independent variable, represented by strategic leadership in its dimensions (defining strategic direction; 
investing strategic capabilities; promoting human capital; enhancing organisational culture with ethical practices; implementing balanced organisational supervision) and relying on some previous studies to prepare the paragraphs related to strategic leadership Hitt et al. (2011), Ireland and Hitt (2005), A. Obeidat (2019), Mubarak and Yusoff (2019), Kitonga (2017) and the dependent variable, represented by organisational ambidexterity with its dimensions (i.e., exploration and exploitation) and relying on some previous studies in order to prepare the paragraphs related to organisational ambidexterity O'Reilly and Tushman (2008), Severgnini et al. (2018), Elfindah (2020), Palm and Lilja (2017). The study questionnaire consisted of 34 items, and was distributed amongst the study variables and their dimensions, as shown in Table 3. The questionnaire was notably distributed to all the items of the study sample electronically via the Google Forms application so that unanswered questions were not accepted, the respondent being reminded of the necessity to return to the question and answer it. Here, the researcher uses the five-point Likert Scale and assigns the scores 5, 4, 3, 2, and 1 to the options strongly agree, agree, average, disagree, and strongly disagree respectively.

\subsection{VALIDITY AND RELIABILITY}

In order to ascertain the apparent validity of the study tool, the study tool was judged by presenting it to a group of referees from academic professors to express an opinion concerning the validity of the questionnaire to collect data related to the study variables, their clarity, coherence, cohesion, accuracy of translation, and any remarks they deem appropriate in terms of addition, deletion, or modification. Indeed, the paragraphs have been amended according to the remarks received from the distinguished arbitrators. Factor analysis was performed to ensure the approximate validity of the study tool and to determine the ability of the study tool and its various parts in measuring the relevant variables. Here, the value is acceptable and strong if the result of the testing of the path load values for the vertebrae with its variables is greater than 0.60 Hair et al. (2017). The results of the factor analysis of the study tool can be seen in Figure 2 .

The Composite Reliability (CR) analysis test is one of the convergent validity tests of the study instrument, and is similar to the Cronbach Alpha test in measuring confidence for all study variables. Researchers Fornell and Larcker (1992) considered it to be better than the Cronbach Alpha Test due to its reliance on the values of the path analysis of the study paragraphs in measuring the consistency of the answers of the study sample individuals-in contrast to the Cronbach alpha test, which assumes constant path analysis values for all items of the study, deeming the value of CR as acceptable if it is greater than 0.70 Hair et al. (2017). The Average Variance Extracted (AVE) test is also considered to be one of the tests of convergent validity of the study instrument, measuring all the variables in the study model. Here, the test value is deemed acceptable if it is greater than 0.50 Hair et al. (2017). This means that the variables of the study model measure more than $50 \%$ of the variance in the paragraphs of the study tool. The results of aforementioned test can be seen in Table 3 .

Table 3 Validity and Reliability

\begin{tabular}{|c|c|c|c|c|c|}
\hline Items & Statements & Mean & S D & CR & AVE \\
\hline & Strategic Leadership & 3.683 & 0.579 & 0.940 & 0.724 \\
\hline 1 & $\begin{array}{l}\text { The KADDB is developing a strategic vision that outlines the direction } \\
\text { of the KADDB and its expected future. }\end{array}$ & 3.698 & 0.798 & & \\
\hline 2 & The KADDB has a strategic plan that is based on a vision for the KADDB. & 3.744 & 0.723 & & \\
\hline 3 & $\begin{array}{l}\text { The KADDB Vision is used as a working guide for many aspects of the } \\
\text { KADDB. }\end{array}$ & 3.723 & 0.821 & & \\
\hline
\end{tabular}




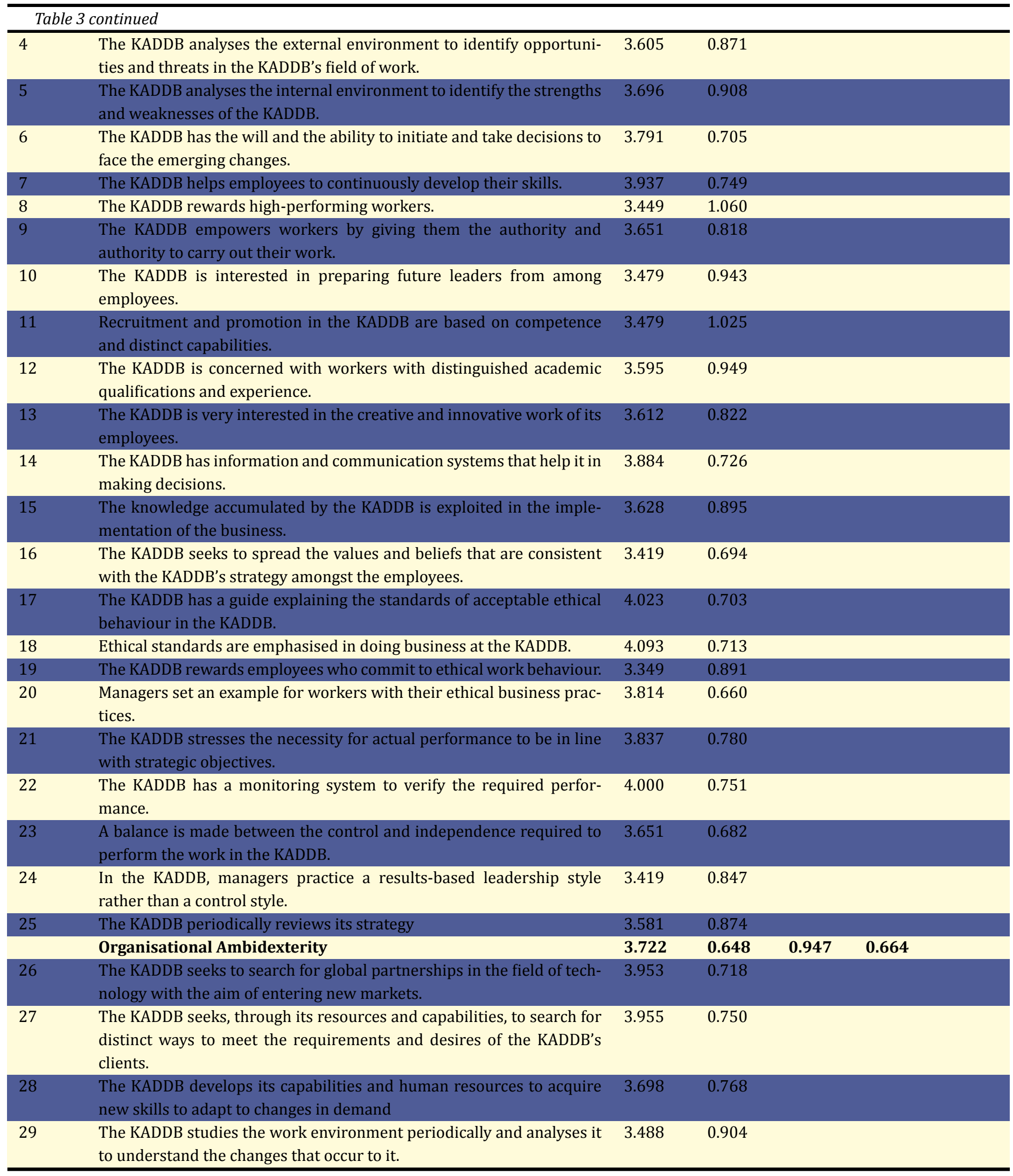




\begin{tabular}{llll}
\hline \multicolumn{2}{c}{ Table 3 continued } & & \\
\hline 30 & $\begin{array}{l}\text { The KADDB makes continuous product adjustments to ensure the con- } \\
\text { tinued loyalty of its customers. }\end{array}$ & 3.767 & 0.777 \\
31 & $\begin{array}{l}\text { The KADDB is constantly striving to increase its market share through } \\
\text { strategic alliances. }\end{array}$ & 3.721 & 0.849 \\
32 & $\begin{array}{l}\text { The KADDB seeks to take advantage of the economies of scale. } \\
\text { The KADDB works to develop its technical skills to take advantage of } \\
\text { modern technological developments. }\end{array}$ & 3.860 & 0.635 \\
\hline 34 & $\begin{array}{l}\text { The KADDB has enough knowledge about competitors' products to use } \\
\text { in developing new products. }\end{array}$ & & 0.904 \\
\hline
\end{tabular}

This is an indication of the consistency between the paragraphs of the study tool and the credibility and reliability of the study tool for conducting statistical analysis.

\subsection{HYPOTHESES TESTING RESULTS}

Correlation was tested and multiple linear regression analysed for the main hypothesis, which was as follows: 'There is no statistically significant impact at a significant level $(\mathrm{P} \geq 0.05)$ for strategic leadership in its dimensions (defining strategic direction, investing strategic capabilities, promoting human capital, enhancing organisational culture with ethical practices, implementing balanced organisational supervision) on organisational ambidexterity with its dimensions (exploration, exploitation) at KADDB.' Here, the significance level ( $\alpha$ level) was 0.05 and the probability value (p) obtained from the statistic hypothesis test was the decision rule to reject the nihilistic hypothesis Creswell (2009). If the value $\mathrm{p}$ is less than or equal to the level $\alpha$, the nihilistic hypothesis will be rejected and the alternative hypothesis will be accepted; however, if the value of $\mathrm{p}$ is greater than the level of $\alpha$, the nihilistic hypothesis will be accepted and the alternative hypothesis will be rejected.

The results of the hypothesis test to measure the impact of strategic leadership practices in organisational ambidexterity, as shown in Table 4 .

Table 4 Results of Testing the Impact of Strategic Leadership on Organisational Ambidexterity

\begin{tabular}{|c|c|c|c|c|c|c|c|c|}
\hline \multirow[t]{2}{*}{$\begin{array}{l}\text { Dependent } \\
\text { Variable }\end{array}$} & $\begin{array}{l}\text { Model } \\
\text { mery }\end{array}$ & Sum- $\quad A$ & \multicolumn{5}{|c|}{ Coefficients } & \multirow[b]{2}{*}{ Sig $\mathrm{t}$} \\
\hline & $\mathbf{R} \quad \mathbf{R}^{2}$ & $\mathbf{F}$ & $\begin{array}{l}\text { Sig } \\
\text { F }\end{array}$ & Description & B & SD & $\mathrm{T}$ & \\
\hline & & & & Defining Strategic Direction & 0.176 & 0.081 & 2.173 & 0.030 \\
\hline & & & & Investing Strategic Capabilities & 0.016 & 0.103 & 0.157 & 0.767 \\
\hline \multirow{3}{*}{$\begin{array}{l}\text { Organisationa } \\
\text { Ambidex- } \\
\text { terity }\end{array}$} & $0.88 \quad 0.781$ & 52.409 & $0.00 c$ & Promoting Human Capital & 0.158 & 0.095 & 1.667 & 0.017 \\
\hline & & & & $\begin{array}{l}\text { Enhancing Organisational Culture } \\
\text { with Ethical Practices }\end{array}$ & 0.324 & 0.098 & 3.304 & 0.001 \\
\hline & & & & $\begin{array}{l}\text { Implementing Balanced Organisa- } \\
\text { tional Supervision }\end{array}$ & 0.321 & 0.120 & 2.658 & 0.008 \\
\hline
\end{tabular}

We notice from Table 4 that the value of the correlation coefficient (R) was 0.884 , thus indicating the existence of a relationship between the independent variables (dimensions of strategic leadership) and the dependent variable (organisational ambidexterity). Here, we additionally note that the value of the determination coefficient (R2) was $(0.781$, which indicates that the combined strategic leadership dimensions explain $78.1 \%$ of the variance in the 


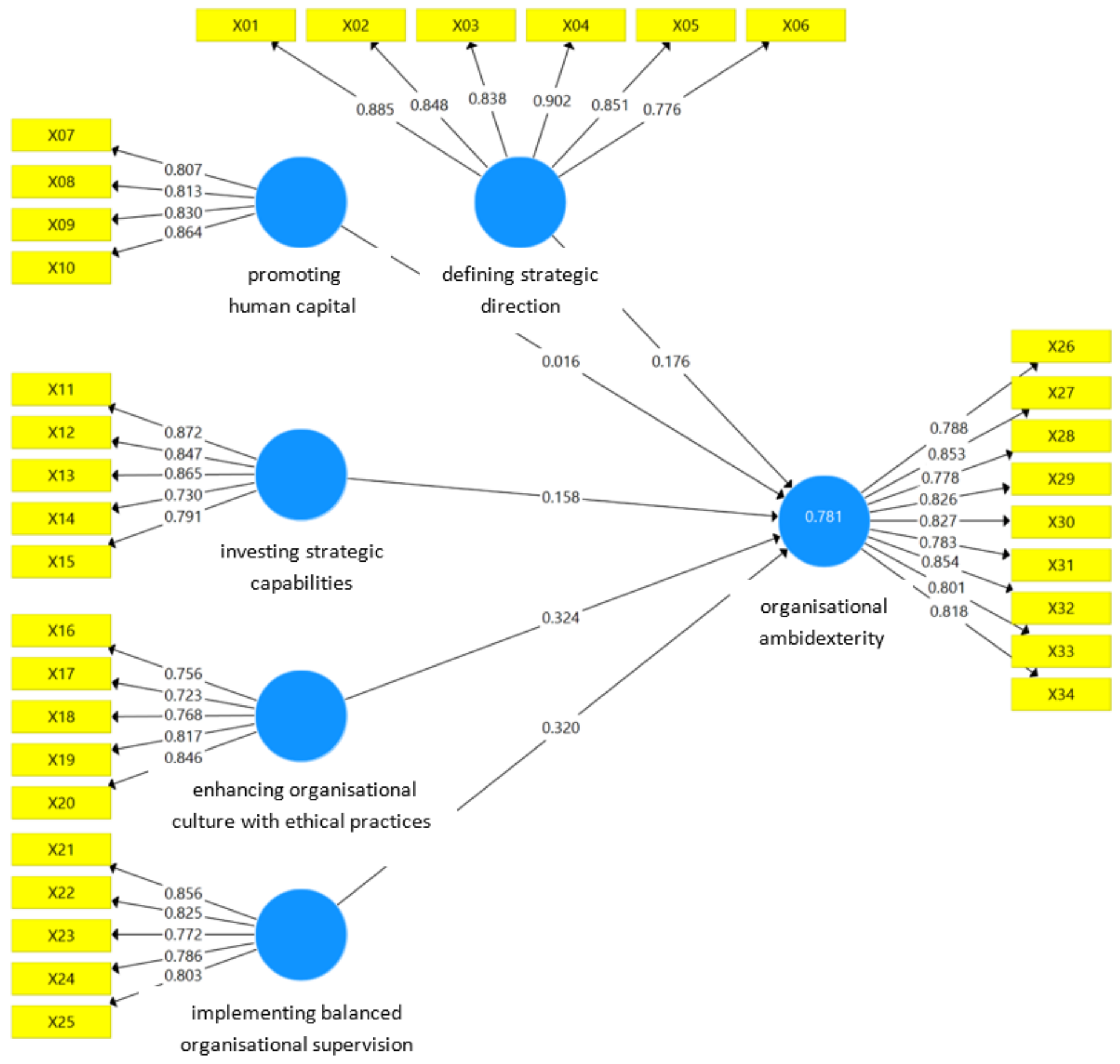

Figure 2 
'organisational skill' dimension. We also note that the value of F was 52.409, with a significant level of Sig $=0.000$. This indicates the significance of the relationship at $(\mathrm{P} \leq 0.05)$.

We also note from the table that the value of B for the dimension 'defining strategic direction' was 0.176 , as well as the fact that this $t$ value reached 2.173, with a significant level of Sig $=0.030$. This indicates that the effect of this dimension is significant at a level of significance $(\mathrm{P} \leq 0.05)$, whilst $\mathrm{B}$ for the dimension 'investing strategic capabilities' was 0.016 , this $t$ value reaching 0.157 with a significant level of Sig $=0.767$. This indicates that the effect of this dimension isn't significant at a level of significance $(\mathrm{P} \leq 0.05)$. Meanwhile, $\mathrm{B}$ for the dimension 'promoting human capital' was 0.158 , this t value reaching 1.667 , with a significant level of $\operatorname{Sig}=0.017$. This indicates that the effect of this dimension is significant at a level of significance $(\mathrm{P} \leq 0.05)$. On the other hand, $\mathrm{B}$ for the dimension 'enhancing organisational culture with ethical practices' was 0.324 , this $t$ value reaching 3.304 with a significant level of Sig = 0.001. This indicates that the effect of this dimension is significant at a level of significance $(\mathrm{P} \leq 0.05)$. Finally, B for the dimension 'implementing balanced organisational supervision' was 0.321 , and this t value reached 2.658 with a significant level of $\mathrm{Sig}=0.008$. This indicates that the effect of this dimension is significant at a level of significance $(\mathrm{P} \leq 0.05)$.

\section{CONCLUSIONS AND DISCUSSIONS}

Based on the above information, we reject the main null hypothesis and accept the alternative main hypothesis as follows: There is statistically significant impact at a significant level $(\mathrm{P} \geq 0.05)$ for strategic leadership in its dimensions (defining strategic direction, investing strategic capabilities, promoting human capital, enhancing organisational culture with ethical practices, and implementing balanced organisational supervision) on organisational ambidexterity with its dimensions (exploration, exploitation) at KADDB.

This result indicates that the strategic leadership has a clear impact on improving the application of organisational ambidexterity at KADDB, also acting as (according to the researchers) evidence of KADDB's awareness (to some extent) of the opportunities and threats in the business environment, as well as its skill in building strategic plans, following up on their implementation, and directing workers to believe in and support them, as well as their exploitation of its distinctive capabilities in achieving its goals. Here, the vital availability of strategic leadership features in the KADDB is indicated-which reflects positively on its application of organisational ambidexterity skills and enables KADDB to achieve competitive advantage and precedence.

These results are in agreement with those of Baškarada et al. (2016), who aimed to demonstrate the impact of strategic leadership on organisational ambidexterity in Australian defence industries companies. Here, they concluded there to be an effect of strategic leadership on organisational ambidexterity in Australian defence industries companies, as well as the fact that the strategic leader's behaviours regarding enhanced exploitation are exemplified by training, performance management, and knowledge management, whilst behaviours promoting exploration are commitment, visibility, risk tolerance, delegation of authority, and inclusiveness. This study is also in agreement with Elfindah (2020), which aimed to identify the factors that aid organisations in activating the activities of organisational ambidexterity, represented by exploitation and exploration, in the era of the Fourth Industrial Revolution. Here, it recommended that managers in senior management possess strategic leadership skills in support of exploration activities, whilst managers in middle management possess strategic leadership skills that support exploitation activities. In the end, the study recommended the necessity of a balance between exploration and exploitation activities, as well as a balance between results-based monitoring and control. We were additionally in agreement with Sibghatullah and Raza (2020), who aimed to demonstrate the impact of strategic leadership on the competitive 
advantage in Jordanian Islamic banks, having the mediating role of organisational ambidexterity and the information system. These results indicated the existence of a statistically significant impact of strategic leadership on the competitive advantage in the Jordanian Islamic banks, the organisational ambidexterity and the information system additionally enhancing the positive impact of this relationship. We are also in agreement with the study of A. M. Obeidat and Thani (2020), which aimed to demonstrate the impact of the strategic leadership in crisis management in the Qatari Ooredoo Company (OOREDOO Q. S. C.). This study concluded there to be an impact of strategic leadership in all its dimensions in managing crises in the company due to the strategic leader's understanding of environmental turmoil and ambiguity, as well as his rational behaviour towards it and developing it in line with a vision/roadmap that enables the organisation to develop and innovate. Our results also supported those of Zaid and N (2016) study, which aimed to demonstrate the impact of strategic leadership on the organisational ambidexterity within Jordanian chemical industries. This study concluded there to be a statistically significant effect of strategic leadership on the organisational ambidexterity in the Jordanian chemical industries, and recommended that managers in such companies focus on the skills of vision, focus, and implementation in order to achieve better performance and ensure the continuation of successful work.

\section{IMPLICATIONS}

This study found the relative importance of the majority of the study's items to be high, thus indicating the great interest of KADDB with all practices and activities of strategic leadership and organisational ambidexterity, as well as KADDB's commitment to ethical standards in carrying out its work. Notably, its administration was keen to serve as a model for employees with their ethical practices, and, indeed, the KADDB seeks to spread the values and beliefs that are consistent with its strategy among workers. Furthermore, the KADDB has the will and ability to initiate and take decisions to face the emerging changes, as well as good knowledge of their strengths and weaknesses, although it needs to improve the knowledge of the opportunities and challenges in the business environment.

In line with the above, the researchers advise the KADDB to enhance the application of organisational ambidexterity by forming work teams that include members with distinguished skills, knowledge, and abilities in the fields of operations, sales, marketing, supply, and research and development, and provide it with appropriate material and technical resources mandated to improve the exploration and exploitation activities in the KADDB. Further to this, the KADDB additionally needs to pay more attention to analysing the work environment periodically in order to understand the changes that occur to it. Additionally, it should examine the feedback of the centre's goods and services further so as to enhance the implementation of exploration activities at the KADDB, as well as to improve its ability to better define its strategic direction. Moreover, it needs to develop the capital of the human centre further by promoting the utilisation of the KADDB's strategic partnerships in the transfer of technology, knowledge, and expertise, as well as the creation of a training centre at the KADDB, developing a program to equip future leaders for the centre and to increase the empowerment of workers by expanding the powers and authorities granted to them.

\section{REFERENCES}

A., Almomani, M., Abujamous, H., \& F. (2020). Decision support system for disaster management proposed conceptual framework. Int. J. Manag. Appl. Sci, 6(4).

Abualoush, S., Masa'deh, R., Bataineh, K., \& Alrowwad, A. (2018). The Role of Knowledge Management Process and Intellectual Capital as Intermediary Variables between Knowledge Management Infrastructure and Organization Performance. Interdisciplinary Journal of Information, Knowledge, and Management, 13, 279-309. Retrieved from https://dx.doi.org/ 


\section{$10.28945 / 408810.28945 / 4088$}

Al-Alwan, A., Artimah, H., Al-Lawzi, \& M. (2019). The strategic leadership competencies and their effect on achieving organizational excellence, through the mediating role of organizational commitment. Business and Management Journal, 7(1), 34-57.

Al-Ammary, S. S., Al-Najjar, \& J, F. (2020). The Impact of Organizational Ambidexterity on Strategic Orientations: The Mediating Role of Organizational Innovation in Private Hospitals in Jordan. European Journal of Scientific Research, 156(1), 58-77.

Alkhaffaf, M. (2018). Investigating the Mediation Role of Information Technology (IT) Components in the Relationship between Knowledge Management (KM) Processes and Decision-Making. International Journal of Business and Management, 13(4), 108-108. Retrieved from https://dx.doi.org/10.5539/ijbm.v13n4p108 10.5539/ijbm.v13n4p108

Al-Zahrani, I. (2018). Strategic leadership and its impact on developing organizational learning capabilities: A field study at Umm Al-Qura University. International Journal of Educational Research, 42(2), 189-238.

Baškarada, S., Watson, J., \& Cromarty, J. (2016). Strategic Leadership and Organizational ambidexterity in Australian Defense Industry Companies. Journal of Management Development, 10(1), 778-788.

Beatty, K., \& Quinn, L. (2012). The role of strategic leadership team in organizations: center for creative leadership. Greensboro, North Carolina, USA: Center for Creative Leadership.

Beer, M., \& Eisenstat, R. A. (2000). The six silent killers of strategy implementation“. Sloan Management Review, 29.

Boal, K. B., \& Hooijberg, R. (2000). Strategic leadership research. The Leadership Quarterly, 11(4), 515-549. Retrieved from https://dx.doi.org/10.1016/s1048-9843(00)00057-6 10.1016/s1048-9843(00)00057-6

Bodwell, W., \& Chermack, T. J. (2010). Organizational ambidexterity: Integrating deliberate and emergent strategy with scenario planning. Technological Forecasting and Social Change, 77(2), 193-202. Retrieved from https://dx.doi.org/10.1016/ j.techfore.2009.07.004 10.1016/j.techfore.2009.07.004

Creswell, J. (2009). Research design: Quantitative, qualitative and mixed method approach. London: Sage.

Danneels, E. (2003). Tight-loose coupling with customers: the enactment of customer orientation. Strategic ManagementJournal, 24(6), 559-576. Retrieved from https://dx.doi.org/10.1002/smj.319 10.1002/smj.319

Davies, B., \& Davies, B. J. (2005). Strategic Leadership. In B. \& Davies (Eds.), Essen-tials of school leadership. Paul Chapman Publishing.

Dhliwayo, S., \& Vuuren, J. J. V. (2007). The strategic entrepreneurial thinking imperative. Acta Commercii, 7(1), 123-134. Retrieved from https://dx.doi.org/10.4102/ac.v7i1.20 10.4102/ac.v7i1.20

Duncan, R. B. (1976). The Ambidextrous Organization: Designing Dual Structures for Innovation. The Management of Organization, 1, 167-188.

Elfindah, P. (2020). Integrating Ambidexterity into the Modern Manufacturing Era of Industry 4.0. Int. J Sup. Chain. Mgt, 9(4), 58-64.

Farghal, M. (2019). The best time to plant a tree. The Business Year, Global Media Group. UK, London.

Fornell, C., \& Larcker, D. F. (1992). Evaluating Structural Equation Models with Unobservable Variables and Measurement Error. Journal of Marketing Research (JMR), 18(1).

Gibson, C. B., \& Birkinshaw, J. (2004). The antecedents, consequences and mediating role of organizational ambidexterity. Academy of Management Journal, 47, 209-226.

Gill, R. (2011). Theory and Practice of Leadership. UK, London: Sage Publications.

Hagen, A., Hassan, M. T., \& Amin, S. G. (1998). Critical strategic leadership components: An empirical investigation. SAM Advanced Management Journal, 63(3), 39-39.

Hair, J. F., Jr, Hult, G. T., Ringle, C. M., \& Sarstedt, M. (2017). Primer on partial least squares structural equation modeling. SAGE Publications, Inc.

Hill, C. W., \& Jones, G. R. (2016). Strategic Management Theory: An Integrated Approach. USA, masatshusts, buastan: Houghton Mifflin, Co.

Hitt, M. A., Haynes, K. T., \& Serpa, R. (2010). Strategic leadership for the 21st century. Business Horizons, 53(5), 437-444. Retrieved from https://dx.doi.org/10.1016/j.bushor.2010.05.004 10.1016/j.bushor.2010.05.004

Hitt, M. A., Ireland, R. D., \& Hoskisson, R. E. (2009). Strategic Management: Competitiveness and Globalization - Concepts and Cases. USA, Ohaio: South Western Thomson Learning. 
Hitt, M. A., Ireland, R. D., \& Hoskisson, R. E. (2011). Strategic management: Competitiveness and globalization. USA, Mason, OH: Cengage Southwestern Publishing.

Hoskisson, R., Hitt, M., \& Ireland, R. D. (2004). Strategic leadership. in competing for advantage. Thomson Learning.

House, R. J., \& Aditya, R. N. (1997). The Social Scientific Study of Leadership: Quo Vadis? Journal of Management, 23(3), 409-473. Retrieved from https://dx.doi.org/10.1177/014920639702300306 10.1177/014920639702300306

Hrebiniak, L. G. (2008). Making Strategy Work: Overcoming the Obstacles to Effective Execution. Ivey Business Journal, 72(2), $1-6$.

Ireland, R. D., \& Hitt, M. A. (2005). Achieving and maintaining strategic competitiveness in the 21st century: The role of strategic leadership. Academy of Management Perspectives, 19, 63-77. Retrieved from https://dx.doi.org/10.5465/ame.2005 .19417908 10.5465/ame.2005.19417908

Jansen, J., George, G., Den, B. V., Frans, A., \& Volberda, W. (2010). Senior team attributes and organizational ambidexterity: The moderating role of transformational leadership. Journal of Management Studies, 45(5), 982-1007.

Judge, W., \& Blocker, C. (2008). Commentary organizational capacity for change and strategic ambidexterity Flying the plane while rewiring it. European Journal of Marketing, 42(9), 915-926.

Kaplan, R. S., \& Norton, D. P. (2004). Strategy Maps: Turning Intangible Assets into Tangible Results. Boston, MA: Harvard Business School Press.

Kitonga, D. (2017). SL practices and organizational performance in not-for-profit organizations in Nairobi county in Kenya. Unpublished Doctoral Dissertation. Kenya.

Lear, L. W. (2012). The relationship between strategic leadership and strategic alignment in high-performance companies in South Africa. Doctoral dissertation.

MITCHELL, R. S., LYNCH, L. J., \& CASIMIR, D. J. (2007). A new method of shelling green peas for processing (Vol. 4) (No. 1). Harlow, England: Wiley. Retrieved from https://dx.doi.org/10.1111/j.1365-2621.1969.tb01497.x 10.1111/j.1365-2621 .1969.tb01497.x

Mohammad, A., \& Hijawi, G. (2019). Impact of Organizational Ambidexterity on Environmental Turbulence of telecommunication companies in Jordan: Resource Flexibility as a Moderator. Interceincia Journal(5), 44-44.

Mubarak, M. F., \& Yusoff, W. F. W. (2019). Impact of Strategic Leadership on Strategy Implementation in Malaysian Industrial Companies. British Journal of Management and Marketing Studies, 2(1), 32-43.

Muzee, H., Bagire, V., \& Ngoma, M. (2016). Strategic Leadership and Employee Engagement, Evidences from an African Industrial Setting. OALib, 03(08), 1-10. Retrieved from https://dx.doi.org/10.4236/oalib.1102907 10.4236/oalib.1102907

Najm, A., Al-Nuaimi, A, M., \& A. (2012). Leadership intelligence (A vision in strategic leadership). Paper presented at the 11th Annual Scientific Conference. Business Intelligence and Knowledge Economy.

Najmaei, A., Quazi, Z., \& Behnia, M. (2017). Balancing strategic leadership: a synthesis of balanced scorecard and strategic leadership theories. Macquarie Graduate School of Management. Sydney, Australia.

Neuman, W. L. (2000). Social Research Methods(2).

Neumann, Y., \& Neumann, E. F. (1999). The president and the college bottom line: the role of strategic leadership styles. International Journal of Educational Management, 13(2), 73-81. Retrieved from https://dx.doi.org/10.1108/ 09513549910261131 10.1108/09513549910261131

Norzailan, Z., Yusof, S. M., \& Othman, R. (2015). Developing Strategic Leadership Competencies. Journal of Advanced Management Science, 4(1), 66-71. Retrieved from https://dx.doi.org/10.12720/joams.4.1.66-71 10.12720/joams.4.1.66-71

Obeidat, A. (2019). IT adaption with knowledge conversion process (SECI). Management Science Letters, 9(13), 2241-2252.

Obeidat, A. M., Abualoush, S. H., Irtaimeh, H. J., Khaddam, A. A., \& Bataineh, K. A. (2018). The role of organisational culture in enhancing the human capital applied study on the social security corporation. International Journal of Learning and Intellectual Capital, 15(3), 258-258. Retrieved from https://dx.doi.org/10.1504/ijlic.2018.094718 10.1504/ijlic.2018 .094718

Obeidat, A. M., \& Thani, F. B. H. A. (2020). The Impact of Strategic Leadership on Crisis Management. International Journal of Asian Social Science, 10(6), 307-326. Retrieved from https://dx.doi.org/10.18488/journal.1.2020.106.307.326 10.18488/journal.1.2020.106.307.326

O’Reilly, C. A., \& Tushman, M. L. (2008). Ambidexterity as a dynamic capability: Resolving the innovator's dilemma (Vol. 28). Cam- 
bridge, MA: Elsevier BV. Retrieved from https://dx.doi.org/10.1016/j.riob.2008.06.002 10.1016/j.riob.2008.06.002

O’Reilly, C. A., \& Tushman, M. L. (2011). Organizational Ambidexterity in Action: How Managers Explore and Exploit. California Management Review, 53(4), 5-22. Retrieved from https://dx.doi.org/10.1525/cmr.2011.53.4.5 10.1525/cmr.2011.53.4.5

Palladan, A. A., Abdulkadir, K. B., \& Chong, Y. W. (2016). The Effect of Strategic Leadership, Organization Innovativeness, Information Technology Capability on Effective Strategy Implementation: A Study of Tertiary Institutions in Nigeria. IOSR Journal of Business and Management, 18(09), 109-115. Retrieved from https://dx.doi.org/10.9790/487x-180901109115 $10.9790 / 487 \mathrm{x}-180901109115$

Palm, K., \& Lilja, J. (2017). Key enabling factors for organizational ambidexterity in the public sector. International Journal of Quality and Service Sciences, 9(1), 2-20. Retrieved from https://dx.doi.org/10.1108/ijqss-04-2016-0038 10.1108/ijqss -04-2016-0038

Pearce, J. A., \& Robinson, R. B. (2007). Formulation, Implementation and Control of Competitive Strategy, (ed). Boston, MA: McGraw-Hill Irwin.

Pisapia, J. (2009). The Strategic Leader: New Tactics for a Globalizing World. Charlotte, NC, USA: Information Age Pub.

Pitelis, C. N., \& Wagner, J. D. (2019). Strategic Shared Leadership and Organizational Dynamic Capabilities. The Leadership Quarterly, 30, 233-242. Retrieved from https://dx.doi.org/10.1016/j.leaqua.2018.08.002 10.1016/j.leaqua.2018.08.002

Preda, G. (2014). Organizational ambidexterity and competitive advantage: Toward a research model. Management and Marketing Journal, 15(1), 68-74.

Ravasi, D., \& M, S. (2016). Responding to Organizational Identity Threats: Exploring the Role of Organizational Culture. Academy of Management Journal, 433-458.

Samba, C., Knippenberg, D. V., \& Miller, C. C. (2018). The impact of strategic dissent on organizational outcomes: A metaanalytic integration. Strategic ManagementJournal,39(2), 379-402. Retrieved from https://dx.doi.org/10.1002/smj.2710 $10.1002 / \mathrm{smj} .2710$

Sayed, A., \& Theeb, K. (2019). The impact of strategic leadership on marketing excellence at Jordanian special hospitals. Islamic University for Economic and Managerial Studies, 2, 117-142.

Schreuders, J., \& Legesse, A. (2012). Organizational Ambidexterity: How Small Technology Firms Balance Innovation and Support. Technology Innovation Management Review, 17-21.

Sekaran, U., \& Bougie, R. (2016). Research methods for business: a skill-building approach. USA, San Francisco; New York: John Wiley and Sons. Inc.

Severgnini, E., Vieira, V. A., \& Galdamez, E. V. C. (2018). The indirect effects of performance measurement system and organizational ambidexterity on performance. Business Process Management Journal, 24(5), 1176-1199. Retrieved from https:// dx.doi.org/10.1108/bpmj-06-2017-0159 10.1108/bpmj-06-2017-0159

Sibghatullah, A., \& Raza, M. (2020). The Impact of Strategic Leadership on Competitive Advantage: The Mediating Role of Ambidexterity and Information System: Evidence from Islamic Banks in Jordan. IJIIS: International Journal of Informatics and Information Systems, 3(2), 67-80. Retrieved from https://dx.doi.org/10.47738/ijiis.v3i2.67 10.47738/ijiis.v3i2.67

Sidhu, J. S. (2004). Business-Domain Definition and Performance: An Empirical Study. SAM Advanced Management Journal, 4045.

Snehvrat, S., Kumar, A., Kumar, R., \& Dutta, S. (2018). The state of ambidexterity research: a data mining approach. International Journal of Organizational Analysis, 26(2), 343-367. Retrieved from https://dx.doi.org/10.1108/ijoa-06-2017-1182 10 .1108/ijoa-06-2017-1182

Sun, X., Zhu, F., \& Sun, M. (2018). How to solve the dilemma of balancing between efficiency and flexibility in project-oriented organizations. Nankai Business Review International, 9(1), 33-58. Retrieved from https://dx.doi.org/10.1108/nbri-04 -2017-0016 10.1108/nbri-04-2017-0016

Thompson, J. L. (1997). Strategic management: Awareness and Change (3), International Thompson Business. tials of school leadership. London: Paul Chapman Publishing.

Trends in world military expenditure in 2019. (n.d.). , Stockholm international peace research institute. Retrieved from https:// www.sipri.org/

Wheelen, T., Hunger, D., Hoffman, A., \& Bamford, C. (2017). Strategic Management and Business Policy - Globalization, Innovation, and Sustainability (15). England; Edinburgh Gate: Pearson Education, Inc. 
Wright, P., Kroll, M. J., \& Parnell, J. A. (2018). Strategic Management Concepts. Upper Saddle River: Prentice - Hall.

Zaid, A., \& N, A. (2016). Testing the Impact of Strategic Leadership on Organizational Ambidexterity: A Field Study on the Jordanian Chemical Manufacturing Companies. International Journal of Business and Management, 11(5), 328-328. 